\title{
PEMBERDAYAAN MASYARAKAT BERBASIS ONE VILLAGE ONE PRODUCT : JASUCI SEBAGAI PRODUK UNGGULAN CISANTANA DALAM MENCIPTAKAN ENTERPRENEUR BERBASIS POTENSI DESA
}

\author{
Neni Nurhayati \\ Program Studi Akuntansi, Universitas Kuningan, Indonesia \\ E-mail: neni.nurhayati@uniku.ac.id
}

\begin{abstract}
Its strategic location with abundant natural potential and supported by relatively cool temperatures makes Cisantana Village a tourism area that offers natural beauty. This potential should be an opportunity for the local community to obtain economic benefits in the form of a potential source of income for the welfare of the local community. However, unfortunately, this potential has not been optimally empowered by the local community. This is evident from the lack of economy in Cisantana Village in the field of home industry. One Village One Product (OVOP) is here to be able to answer the problems that Cisantana Village and other villages have in order to be able to develop regional potential into a superior regional product while still paying attention to its distinctive characteristics and potential. The purpose of this community service implementation is to provide understanding, knowledge and insight regarding the optimization of superior village products to be used as a source of income for the local community. The service methods used are lectures, workshops, practice, and activity evaluation. The result of this community service is the development of superior village products $(O V O P)$ in the form of processed ginger products called Jasuci (Cisantana milk ginger). This product is expected to become an icon of Cisantana Village and be accepted by the wider community.
\end{abstract}

Keywords: OVOP, entrepreneur, village potential

\begin{abstract}
Abstrak
Letaknya yang sangat strategis dengan potensi alam yang melimpah dan didukung suhunya yang relatif sejuk menjadikan Desa Cisantana menjadi kawasan pariwisata yang menawarkan keindahan alam. Potensi ini seharusnya menjadikan sebuah peluang untuk masyarakat setempat memperoleh manfaat ekonomi berupa potensi sumber pendapatan untuk kesejahteraan masyarakat setempat. Namun sayangnya, potensi-potensi yang dimiliki ini belum optimal diberdayakan masyarakat setempat. Hal tersebut terbukti dari perekonomian Desa Cisantana dalam bidang home industry masih terbilang kurang. One Village One Product (OVOP) hadir untuk dapat menjawab permasalahan yang dimiliki Desa Cisantana juga desa lainnya untuk dapat mengembangkan potensi daerah menjadi sebuah produk unggulan daerahnya dengan tetap memperhatikan ciri khas juga potensi yang dimiliki. Tujuan pelaksanaan pengabdian kepada masyarakat ini adalah untuk memberikan pemahaman, pengetahuan dan wawasan mengenai optimalisasi produk unggulan desa untuk dapat dijadikan sebagai sumber pendapatan bagi masyarakat setempat. Metode pengabdian yang digunakan yaitu ceramah, workshop, praktik, dan evaluasi kegiatan. Hasil dari pengabdian kepada masyarakat ini berupa pengembangan produk unggulan desa (OVOP) berupa produk olahan jahe yang disebut dengan Jasuci (jahe susu Cisantana). Produk ini diharapkan bisa menjadi ikon Desa Cisantana dan dapat diterima oleh masyarakat luas.
\end{abstract}

Kata Kunci : OVOP, enterpreneur, potensi desa 


\section{PENDAHULUAN}

Desa Cisantana merupakan salah satu desa di Kecamatan Cigugur Kabupaten Kuningan Jawa Barat. Desa Cisantana terletak di bawah kaki Gunung Ciremai. Dilihat dari lokasinya, Desa Cisantana memiliki potensi sumber daya alam yang melimpah berupa hasil pertanian dan perkebunan. Hal tersebut menjadikan Desa Cisantana menjadi desa penghasil tanaman pangan dan ternak. Selain itu, Desa Cisantana juga menawarkan keragaman potensi pariwisata alam yang sangat menarik.

Letaknya yang sangat strategis dengan potensi alam yang melimpah dan didukung suhunya yang relatif sejuk menjadikan Desa Cisantana menjadi kawasan pariwisata yang menawarkan keindahan alam. Hal ini merupakan salah satu kelebihan yang dimiliki desa tersebut. Potensi ini seharusnya menjadikan sebuah peluang untuk masyarakat setempat memperoleh manfaat baik manfaat ekonomi maupun manfaat dari segi lainnya. Manfaat ekonomi yang bisa diperoleh dari adanya potensi ini yaitu menciptakan sebuah sumber pendapatan untuk kesejahteraan masyarakat setempat. Namun sayangnya, potensi-potensi yang dimiliki ini belum optimal diberdayakan masyarakat setempat. Hal tersebut terbukti dari perekonomian Desa Cisantana dalam bidang home industry masih terbilang kurang. Hal ini menjadi sebuah tugas bersama seluruh pemangku kepentingan untuk dapat mengoptimalkan potensi yang dimiliki sehingga menjadikan sebuah kekuatan yang bisa dijadikan sumber pendapatan bagi masyarakat sehingga hasilnya dapat meningkatkan kesejahteraan khususnya bagi masyarakat setempat.

One Village One Product (OVOP) hadir untuk dapat menjawab permasalahan yang dimiliki Desa Cisantana juga desa lainnya untuk dapat mengembangkan potensi daerah menjadi sebuah produk unggulan daerahnya dengan tetap memperhatikan ciri khas juga potensi yang dimiliki masing-masing daerah tersebut. Program OVOP ini merupakan sebuah program kolaborasi antara berbagai pihak seperti UMKM, BUMDES, Pemda, masyarakat, dan seluruh stakeholder dalam meningkatkan added value serta kemandirian desa dengan berdasar pada potensi khas daerah yang dimiliki. Desa cisantana merupakan desa yang mayoritas masyarakatnya berkebun dimana salah satu hasil perkebunan nya berupa tanaman jahe. Selain itu, masyarakat Desa Cisantana juga banyak memelihara hewan ternak berupa sapi yang menghasilkan susu. Hal ini menjadikan salah satu potensi Desa Cisantana yang dapat dikembangkan adalah berupa olahan jahe dan susu. Produksi Jahe di Desa Cisantana terbilang banyak dan dapat dikembangkan menjadi sebuah produk olahan yang memiliki nilai tambah. Letaknya yang berada di ketinggian -/+ 1000 meter diatas permukaan laut, menjadikan Desa Cisantana memiliki suhu udara yang sangat dingin.

Hal ini juga menjadi sebuah kekuatan yang dapat diangkat untuk bisa menciptakan produk olahan jahe. Olahan jahe yang identik dapat hangat sehingga dapat menghangatkan tubuh menjadi sebuah keunggulan tersendiri. Olahan jahe ini diharapkan dapat menjadi ikon Desa Cisantana dan mampu diterima masyarakat luas. Produk olahan jahe yang diangkat yaitu Jasuci. Jasuci merupakan minuman yang terbuat dari olahan jahe. Dalam pelaksanaanya minuman jahe ini tidak hanya minuman yang terbuat dari jahe akan tetapi terdapat varian lain dari produk ini yaitu jahe susu Cisantana yang merupakan paduan antara jahe dan susu sapi.

Dalam kegiatan kerjasama ini Universitas Kuningan dipercaya sebagai fasilitor melalui kegiatan pengabdian kepada masyarakat yang bertujuan untuk Optimalisasi 
Pemberdayaan Masyarakat dengan Menciptakan Enterpreneur Berbasis Potensi Desa Adapun dalam memberdayakan masyarakat desa melalui kegiatan pengabdian seperti penyuluhan, pelatihan dan pendampingan. Berdasarkan permasalahan di atas penulis tertarik untuk melakukan program pengabdian kepada masyarakat dengan tema Pemberdayaan Masyarakat Berbasis One Village One Product; Jasuci Sebagai Produk Unggulan Desa Cisantana Dalam Menciptakan Enterpreneur Berbasis Potensi Desa.

\section{METODE PELAKSANAAN}

Berdasarkan permasalahan yang sudah diidentifikasi dan dirumuskan di atas, maka metode pelaksanaan kegiatan yang digunakan dalam pengabdian ini menggunakan metode antara lain:

1. Pelatihan merupakan proses belajar mengajar dengan menggunakan teknik dan metode tertentu secara konsepsional dengan tujuan untuk meningkatkan keterampilan dan kemampuan seseorang atau sekelompok orang (Siagian dalam Lubis, 2008). Adapun teknik yang digunakan dalam metode pelatihan ini yaitu:

a) Teknik presentasi informasi yang meliputi ceramah dan diskusi

b) Metode simulasi yang meliputi studi kasus, permainan bisnis dan latihan proses pencatatan maupun pelaporan akuntansi keuangan masjid

2. Pendampingan dilakukan dengan pendekatan individual.

Adapun langkah-langkah kegiatan yang dilakukan adalah sebagai berikut: Sosialisasi OVOP, FGD dengan pihak masyarakat, perangkat desa dan Bumdes setempat terkait identifikasi peluang bisnis dengan memanfaatkan potensi yang tersedia di Desa Cisantana, Sosialisasi tentang manajemen bisnis dan strategi pemasaran termasuk perhitungan keuangan dan Demo Pembuatan Jasuci

\section{HASIL DAN PEMBAHASAN}

Acara puncak Kegiatan Pengabdian kepada Mayarakat (PkM) telah dilakukan selama 3 (tiga) hari dimulai tanggal 23 sampai dengan tanggal 25 Agustus 2019. Kegiatan workshop ini bertempat di Desa Cisantana Kecamatan Cigugur Kabupaten Kuningan Jawa Barat. Kegiatan tersebut berjalan lancar dan sesuai dengan yang telah ditargetkan sebelumnya. Antusiasme masyarakat terlihat begitu jelas dengan dibuktikan masyarakat yang hadir pada saat itu sebanyak 38 orang dari 40 peserta yang diundang. Selama kegiatan berlangsung terlihat keaktifan dari masyarakat dalam merespon berbagai kajian yang kami bawakan baik itu menjawab pertanyaan atau mengajukan pertanyaan. Kegiatan pelatihan ini didukung oleh semua elemen masyarakat desa.

Gambar 1. Spanduk pelaksanaan kegiatan

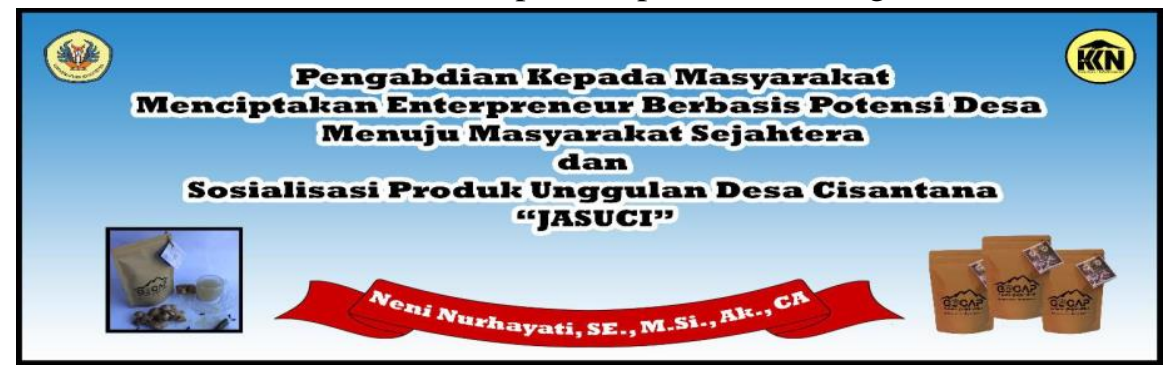


Pada tahap pertama dilakukan sosialisai terkait program OVOP. Pada tahapan ini peserta diberikan pemahaman terkait pentingnya program ovop dengan berbagai tujuan positif dalam rangka mengembangkan potnsi daerah sehingga dapat dijadikan sebuah langkah dalam upaya meningkatkan kesejahteraan masyarakat di daerah tersebut.

\section{Gambar 2. Penyampaian Materi Workshop}

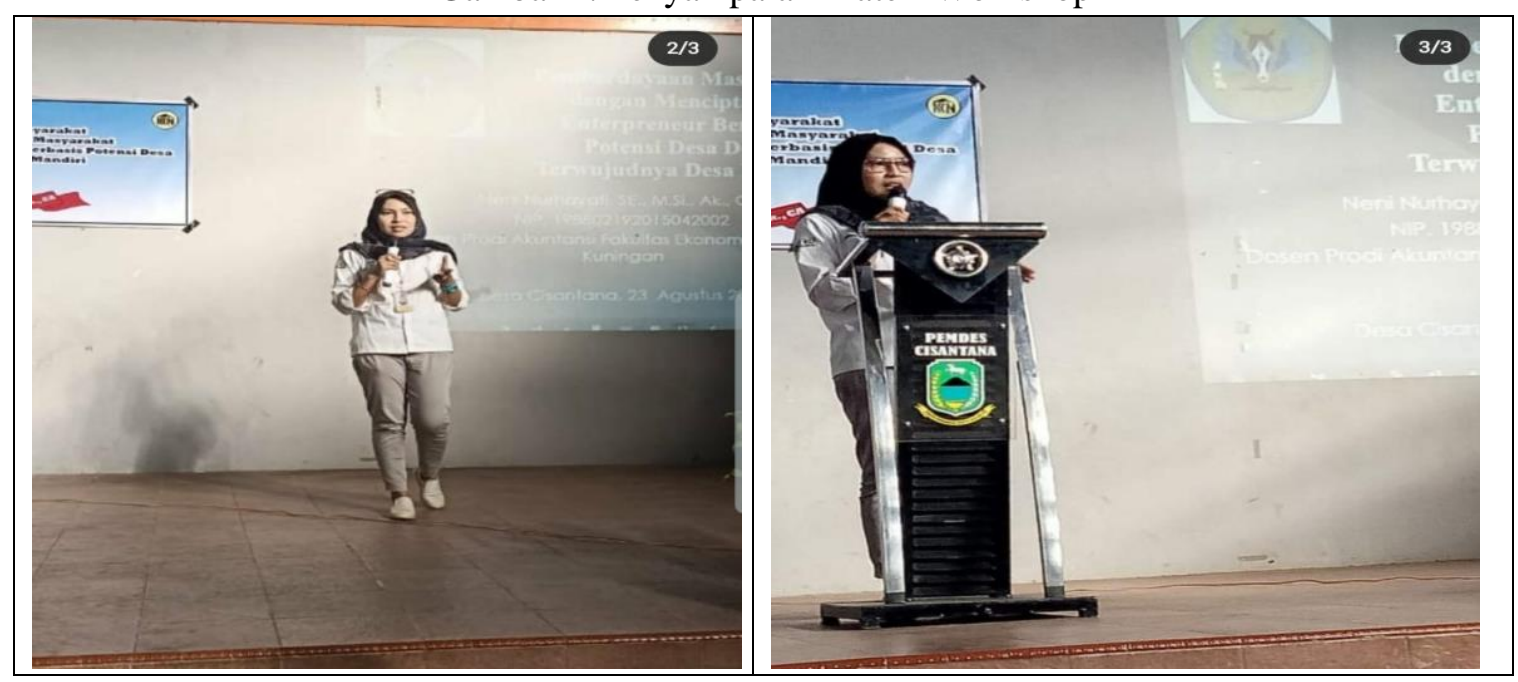

Tahapan selanjutnya yaitu FGD dengan pihak masyarakat, perangkat desa dan Bumdes setempat terkait identifikasi peluang bisnis dengan memanfaatkan potensi yang tersedia di Desa Cisantana. Potensi yang diangkat berupa olahan jahe dan susu sapi. Pada tahapan ini ditawarkan berupa produk olahan jahe dan susu yang diberi nama JASUCI. Jasuci ini kepanjangan dari Jahe Susu Cisantana. Minuman jahe merupakan minuman herbal yang sangat baik dikonsumsi. Selain menyehatkan juga berfungsi sebagai obat bagi tubuh manusia. Jahe memiliki aroma yang khas dan menghangatkan bagi tubuh. Oleh sebab itu, minuman jahe ini sangat cocok untuk dijadikan suatu produk di desa cisantana yang berada didataran tinggi sehingga terasa dingin.

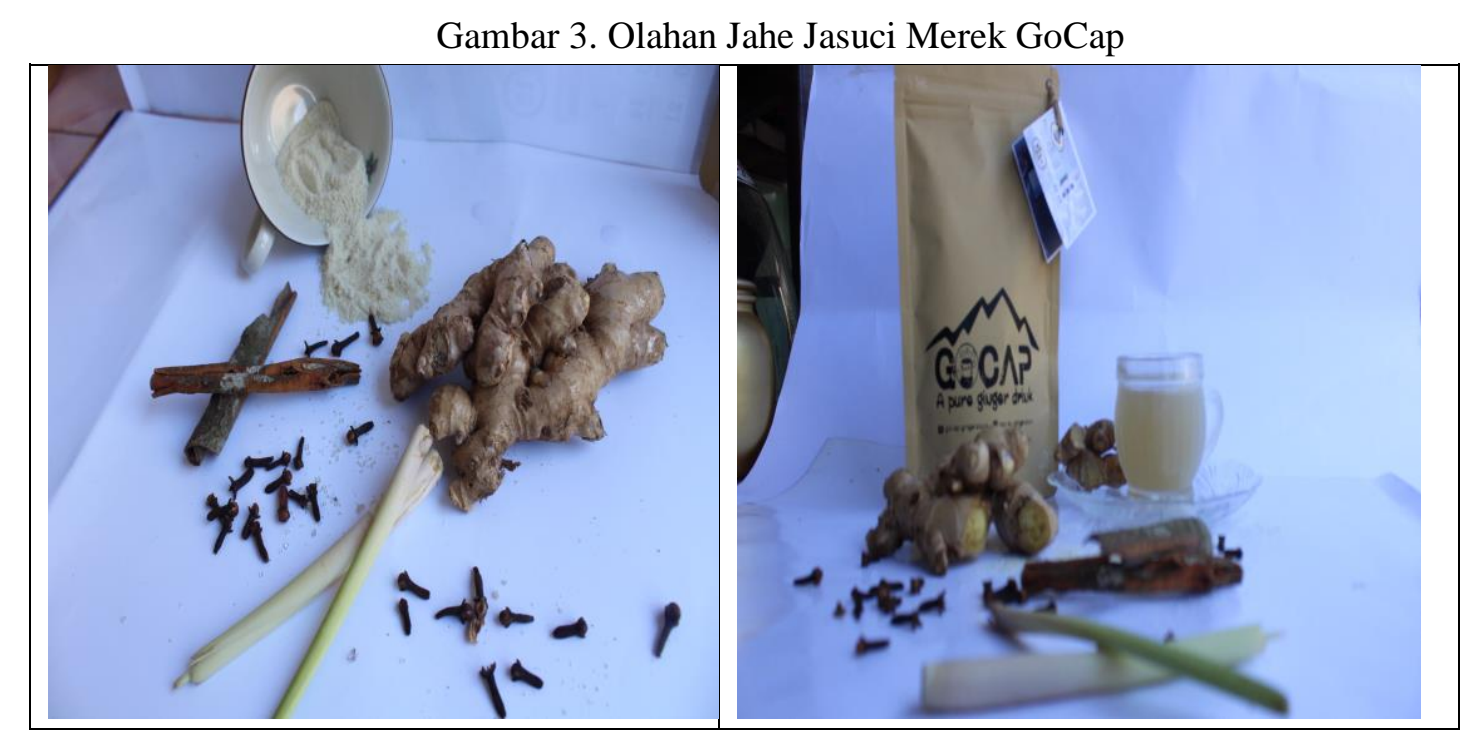




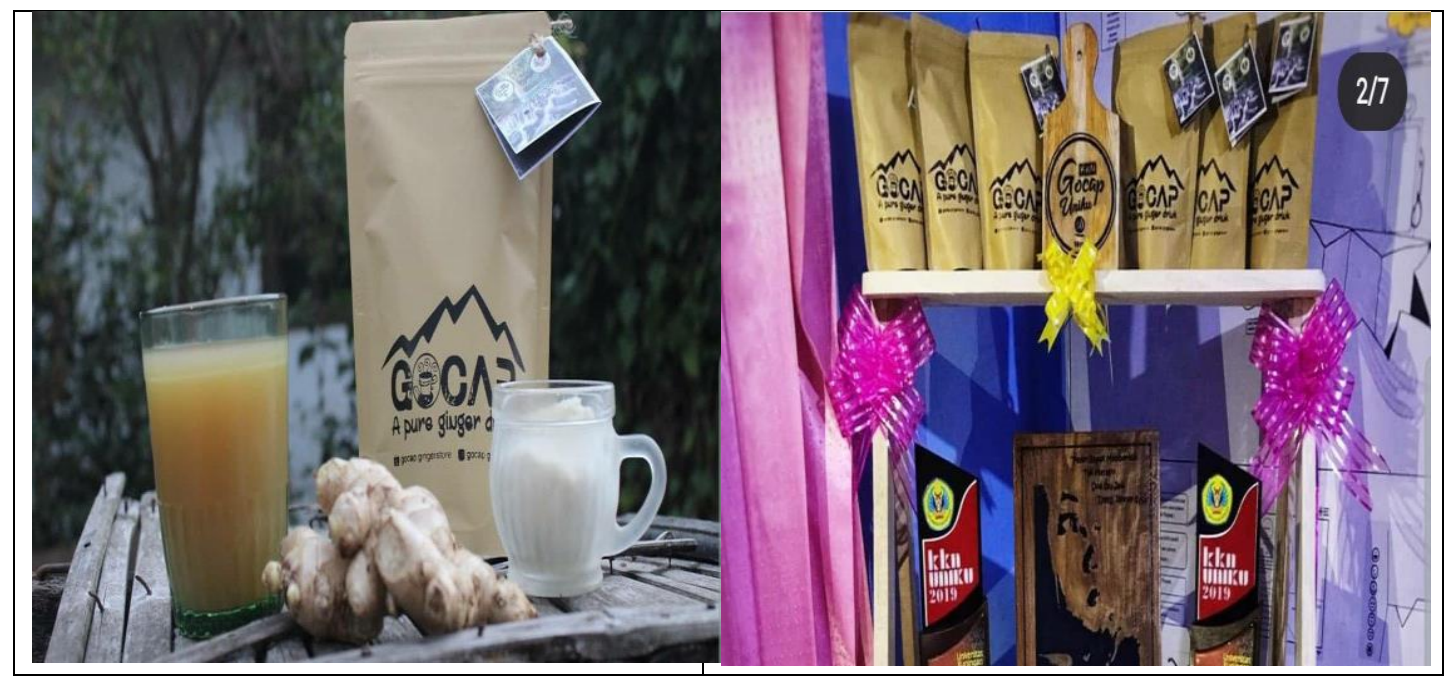

Setelah tahap pertama dan kedua dilalui, tahapan selanjutnya yaitu sosialisasi tentang manajemen bisnis dan strategi pemasaran termasuk perhitungan keuangan. Pemasaran susu jahe ini memiliki peluang bisnis yang sangat menjanjikan. Susu jahe ini cocok dikonsumsi untuk semua kalangan. Susu dan jahe yang terdapat didesa cisantana merupakan aset desa yang dapat dimanfaatkan untuk pembangunan desa cisntana di bidang ekonomi. Tidak menutup kemungkinan akan menambah citra baik bagi desa cisantana dengan menjadikan desa cisantana menjadi desa yang sukses dalam segala bidang, bahagia dan sejahtera dalam biodang ekonomi dengan menjalankan usaha produk minuman serbuk susu jahe. Pada tahapn ini juga di bahas mengenai biaya produksi, perhitungan laba rugi, dan BEP.

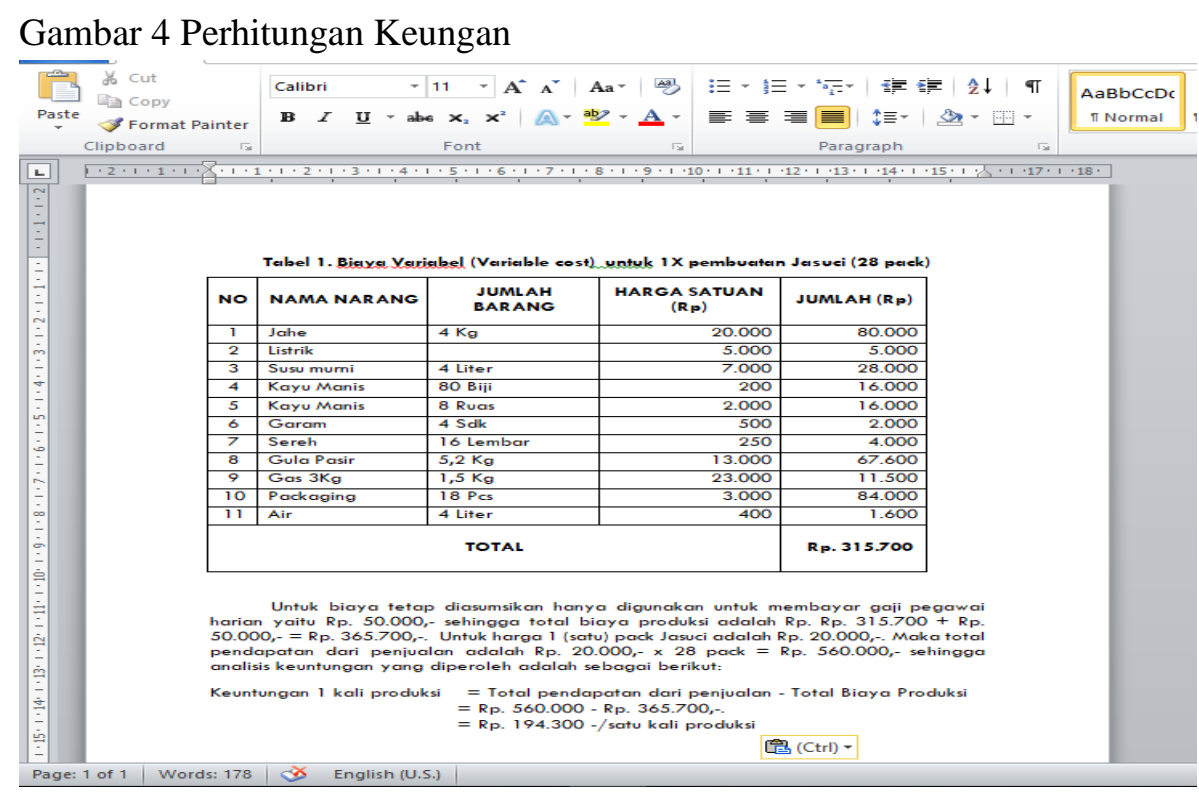

Tahapan selanjutnya yaitu Demo Pembuatan Jasuci. Pada tahap ini dijelaskan bahan dan alat apa saja yang dibutuhkan sampau pada tahap produksi dan pengemasan Jasuci. 
Gambar 5. Demo Pembuatan Jasuci

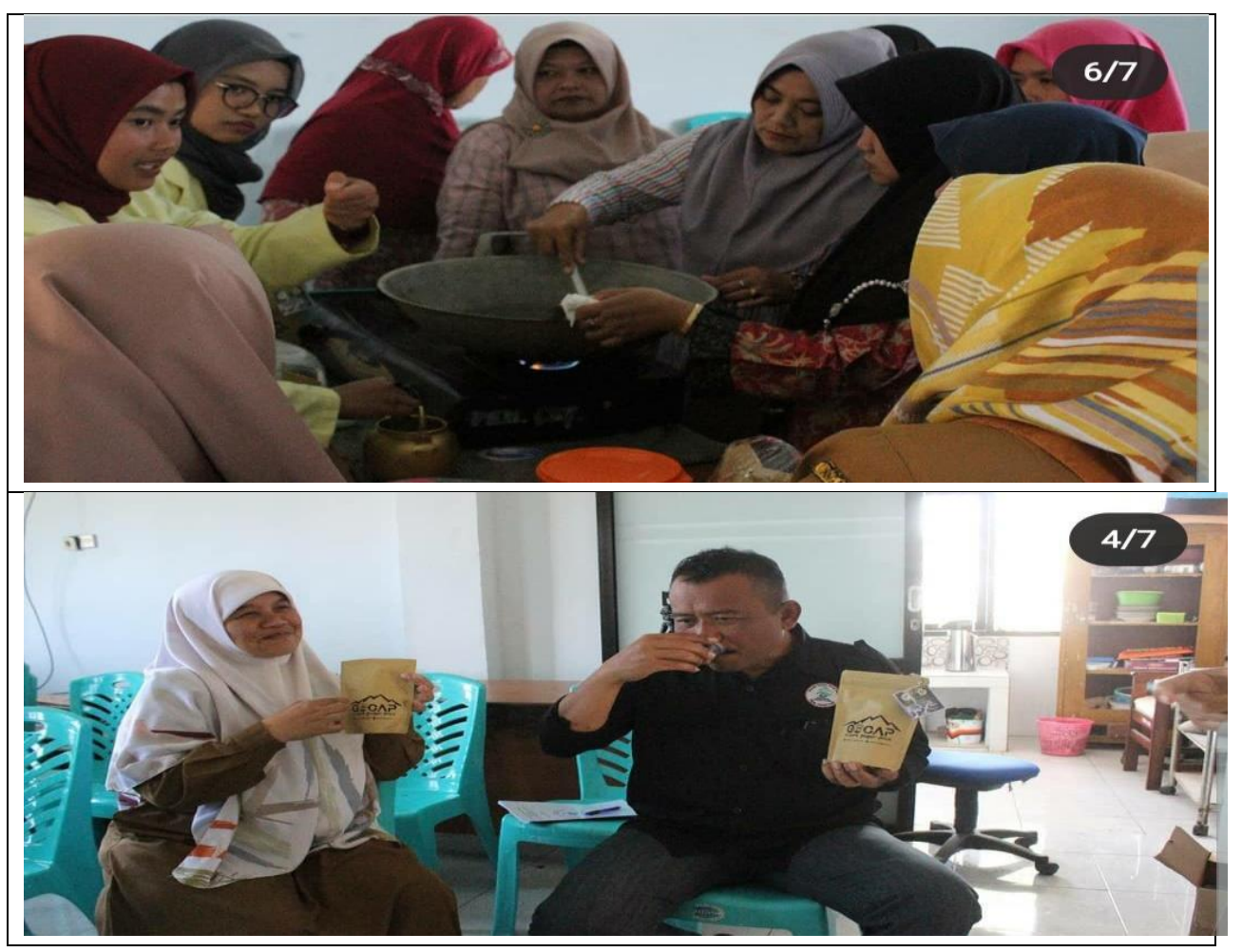

\section{SIMPULAN}

Pelaksanaan kegiatan pengabdian pada masyarakat (PkM) telah dilakukan selama 3 (tiga) hari dimulai tanggal 23 sampai dengan tanggal 25 Agustus 2019. kegiatan tersebut berjalan dengan lancar berlangung baik dan responsif. Hal ini terlihat dari dukungan dan antusias masyarakat di Desa Cisantana dalam mengikuti kegiatan dari awal sampai akhir. Hasil dari pengabdian kepada masyarakat ini berupa pengembangan produk unggulan desa (OVOP) berupa produk olahan jahe yang disebut dengan Jasuci (jahe susu Cisantana). Produk ini diharapkan bisa menjadi ikon Desa Cisantana dan dapat diterima oleh masyarakat luas.

\section{SARAN}

Pelaksanaan kegiatan evaluasi perlu dilakukan berkala untuk menjamin continuitas keberadaan produk Jasuci. Adanya kolaborasi yang solid antara berbagai pihak perlu untuk dilakukan terus dilakukan dalam pengembangan produk unggulan desa.

\section{UCAPAN TERIMA KASIH}

Penulis ucapkan terimakasih kepada seluruh pihak (Pimpinan Desa Cisantana dan jajarannya, masyarakat Desa Cisantana, Bumdes Desa Cisantana, KKN Uniku Kelompok 50, LPPM Universitas Kuningan, Pimpinan Universitas Kuningan beserta jajarannya) yang telah membantu terlaksananya kegiatan pengabdian kepada masyarakat ini. Kegiatan ini dibiayai dana PkM Internal Universitas Kuningan berdasrkan Surat Persetujuan Rektor No. 828.1/UNIKU-KNG/PP/2019 Tanggal 16 Agustus 2019. 


\section{DAFTAR PUSTAKA}

Alma Buchari.2018. Kewirausahaan Untuk Mahasiswa dan Umum. Bandung: Alfabeta.

Anak Suryo. 2007. Akuntansi Untuk UKM, Metode akuntansi Praktis dan sederhana untuk Usaha Kecil dan Menengah, Media Pressindo.D Made Dharmawati. 2016. Kewirausahaan. Jakarta: PT. Raja Grafindo

Fauziah, dkk. Pemberdayaan Masyarakat Berbasis Teknologi Informasi Untuk Mempromosikan Produk-Produk Unggulan Desa Empowerment : Jurnal Pengabdian Masyarakat, Vol. 03 Nomor 01.2020.67-73

Kasmir. Kewirausahaan. PT. Raja Grafindo Perkasa. Jakarta

LPPM. 2019. Panduan Pengabdian Kepada Masyarakat. Universitas Kuningan

Rusdiana.2013. Kewirausahaan Teori \& Praktik. Bandung: Pustaka Setia.

Sukirno, Sadono. 2006. Ekonomi Pembangunan Edisi Kedua. Kencana. Jakarta

Wennekers, Sander, and Roy Thurik. 1999. Linking Entrepreneurship and Economic Growth. Small Business Economics.

Toto Supartono, dkk. Pemberdayaan Kelompok Penggiat Pariwisata Bumi Perkemahan Pasir Batang Dalam Pemanfaatan Limbah Sayuran Sebagai Pupuk Organik Cair, Desa Karangsari, Kecamatan Darma, Kabupaten Kuningan.Empowerment : Jurnal Pengabdian Masyarakat. Vol. 02.Nomor 02.2019.74-82

Wennekers, Sander, and Roy Thurik. 1999. Linking Entrepreneurship and Economic Growth. Small Business Economics. 